\title{
REDUCTION OF GASEOUS EMISSIONS FROM SHIPS: COMPARATIVE OVERVIEW OF METHODS AND TECHNOLOGIES
}

\author{
MARIA EUGENIA LOPEZ LAMBAS ${ }^{1}$, STEFANO RICCI ${ }^{2} \&$ LUCA RIZZETTO $^{2}$ \\ ${ }^{1}$ Universidad Politecnica de Madrid, Spain \\ ${ }^{2}$ Sapienza Università di Roma, Italy
}

\begin{abstract}
This paper develops a methodology for the systematic estimation of the annual emission of a commercial ship and its environmental costs. By integrating the abatement methods in the process, it is possible to estimate the environmental benefit of emission reduction options, taking into account the operational range of the ship and looking for the best investment option, for both social and ship-owner viewpoints. Finally, the procedure will provide with the classical indicators of cost-benefit and costrevenue analyses, such as net present value (NPV), internal rate of return (IRR) and pay-back period (PBP).

Keywords: ships, environment, emissions, fuels, scrubbers.
\end{abstract}

\section{INTRODUCTION}

International initiatives to reduce ship exhaust emissions are encouraging the maritime industry to develop alternatives to traditional petroleum-based marine fuels. In this framework, the long term, research aims to reduce emissions by alternative fuels and new technologies. They are liquefied natural gas (LNG), liquefied petroleum gas (LPG), methanol, biofuels and hydrogen. Moreover, research also works on innovation in systems to transform and/or store energy, namely fuel cells and batteries.

Meanwhile, in the nearest future, exhaust after treatment systems and low sulphur fuels, such as marine gas oil (MGO) obtained by blending with residual fuels in refineries containing $0.1 \% \mathrm{~m} / \mathrm{m}$ sulphur or less, will continue to be in use to reduce emissions to target levels. Alternatively, exhaust gas cleaning systems (EGCS) (Scrubber) systems, are able to reduce the level of particulate matter and sulphur oxides from the exhaust gas. After the washing process, sulphur oxide and exhaust gas with reduced level of particulate matter release to the atmosphere. In Open Loop Scrubbers, seawater is preferred for the cleaning of exhaust gas. Its effectiveness depends on the chemistry of the water in which the ship operates. Meanwhile Closed Loop Scrubbers use freshwater to clean the exhaust gas, treated with sodium hydroxide $(\mathrm{NaOH})$ in order to return it to the cleaning system.

\section{METHODS TO REDUCE EXHAUST EMISSIONS FROM SHIPS}

This section will look at alternative fuels and new technologies, as well as proposed solutions to reduce exhaust emissions.

\subsection{Alternative fuels}

The maritime transport experienced a transition from coal to diesel in the $1920 \mathrm{~s}$ and then to heavy fuel oil (HFO) in the 1950s. Today, due to the changing regulations to mitigate the negative effects on human health and environment, the shift towards alternative fuels becomes an important option for reducing emission rates and complying with rules issued in favour of the sustainability of maritime transport [1]. In addition to marine fuels with low 
sulphur content, other fuels that can act for the compliance with the regulations are liquefied natural gas (LNG), liquefied petroleum gas (LPG), methanol, biofuels and hydrogen [2].

HFO have a maximum sulphur limit of $3.5 \% \mathrm{~m} / \mathrm{m}$, while MGO, obtained by blending with residual fuels in refineries, contain $0.1 \% \mathrm{~m} / \mathrm{m}$ sulphur or less. The expectation is that blended fuels with low sulphur content, such as fuels today used in Emission Control Areas, will rise at a high rate of use. Therefore, new types of fuel with low sulphur content are entering the market and they need to prepare ships for processes, such as supply, transportation and use of them.

LNG is the cleanest fossil fuel available today. Its main component is methane (CH4), the hydrocarbon fuel with the lowest carbon content; therefore, it is also the alternative fuel with the highest potential to reduce $\mathrm{CO}_{2}$ emissions. Purification of LNG eliminates carbon dioxide and sulphur during the production process; therefore, it cannot generate sulphur oxide emissions. In addition, nitrogen oxide emissions are lower than for the HFO and MGO and, compared to the most widely used high-sulphur fuels, LNG has reduced $\mathrm{CO}_{2}$ emissions by about $25 \%$, nitrogen oxides emissions by $85-90 \%$ and sulphur oxides emissions close to $100 \%$ [3]. Since the boiling point of LNG is about $-163^{\circ} \mathrm{C}$ at 1 bar absolute pressure, its storage must be in insulated tanks 2.5-3 times larger due to the smaller density and the required thermal protection. The price level of LNG is currently competitive with MGO [4]. In parallel with the orders of LNG fuelled ships, there will be significant developments in LNG fuel infrastructure for bunkering and distribution for ships in the coming years. Moreover, the International Safety Code for Ships Using Gas or Other Low-Flash Point Fuels (IGF Code), entered into force in 2017, established an international regulatory basis for the design and construction of LNG-fuelled vessels.

LPG is a mixture of propane and butane in liquid form in various proportions achieving the desired saturation, pressure and temperature characteristics. The boiling point of propane is at $-42^{\circ} \mathrm{C}$ and it is usable as a liquid by applying medium pressure $\left(8.4\right.$ bar at $\left.20^{\circ} \mathrm{C}\right)$. Butane has a boiling point between -0.5 and $-12^{\circ} \mathrm{C}$, both higher than propane; therefore, their liquefaction is possible at low pressure. For land-based storage, propane tanks are equipped with safety valves to keep the pressure below 25 bar and are larger than the fuel storage tanks in the ship due to the low density of LPG. The LPG production increased by approximately $2 \%$ per year in the last 10 years and the current distribution and storage facilities distribution is one of the most important issues for LPG as an alternative fuel. $\mathrm{CO}_{2}$ emissions released when LPG burns are approximately $16 \%$ lower than for HFO but the global warming potential of propane and butane as greenhouse gases is 3-4 times higher than $\mathrm{CO}_{2}$. At the same time, it LPG use drastically reduces sulphur emissions and prevents particulate matter emissions due to its nature.

Methanol chemical structure $\left(\mathrm{CH}_{3} \mathrm{OH}\right)$ ensures low carbon and high hydrogen content. It exists as a liquid at atmospheric pressure between $-93^{\circ} \mathrm{C}$ and $+65^{\circ} \mathrm{C}$. Its productions bases on natural gas or coal, but also from waste $\mathrm{CO}_{2}$ from pulp and paper mills, forest or agricultural waste and even power plants. The use of methanol from natural gas results in significantly lower exhaust emissions, it is without sulphur, toxic, corrosive and liquid fuel under ambient conditions [5]. Due to its density and low heating value $(20.1 \mathrm{MJ} / \mathrm{kg})$, methanol fuel tanks are approximately 2.5 times larger than marine fuel tanks for the same energy content. It has a flash point of $11^{\circ} \mathrm{C}$ and it is convertible into dimethyl-ether (DME), usable as fuel for diesel engines [6]. There are currently dual fuel machines that can run on methanol. Stena Germanica, the world's first methanol-powered ship, has reduced emissions of SOx by $99 \%$, NOx by $60 \%$, particulate matter by $95 \%$ and $\mathrm{CO}_{2}$ by $25 \%$, in full compliance with the Emission Control Areas (ECA) regulations on the Baltic Sea and, as of 2019, there were 11 ships operating with methanol. 
Biofuels derived from primary biomass residues converted into liquid or gaseous fuels. A wide variety of stages is available for the production of biofuels, including: first generation: containing sugar, starch or lipid extracted directly from plants; second generation: obtained from woody crops, purpose-grown food raw materials and waste/residues; Third generation: derived from aquatic autotrophic organisms. The emission reduction potential of biofuels varies widely depending on the specific raw material, biofuel production and engine type/model and supply chain. The most promising biofuels for ships are biodiesel, such as biomass to liquid (BTL), fatty acid methyl ester (FAME) and liquefied biogas (LBG). Biodiesel is the most suitable option to replace MGO and LBG is the best alternative to LNG and flat vegetable oil. Moreover, biofuels is applicable in diesel engines without any change, as their combustion properties are almost the same as conventional diesel [7]. However, the use of biofuels is under internationally restriction due to sustainability issues associated with large-scale production. In general, advanced biofuels have lower greenhouse gas emissions than conventional biofuels.

Hydrogen is a colourless, odourless and non-toxic gas. For the use on board ships, it can be stored as a liquid, compressed gas or linked to a chemical chain. Due to its physical properties, it liquefies only at very low temperatures (below $-253^{\circ} \mathrm{C}$ ) by lowering the temperature and/or increasing the pressure. However, the critical maximal temperature for the liquefaction is $-239.96^{\circ} \mathrm{C}$, therefore, liquefaction of hydrogen often requires cooling and additional compression in the cryogenic hydrogen storage. The specific energy per mass is $119.9 \mathrm{MJ} / \mathrm{kg}$, which is about 3 times higher than the specific energy of HFO and the bulk density of $71 \mathrm{~kg} / \mathrm{m}^{3}$ is only $7 \%$ of the HFO density, resulting in about 5 times the volume of energy stored in the HFO. The present annual production of hydrogen is more than 50 million tons, almost completely obtained from natural gas, which corresponds to the energy intensity of approximately 150 million tons of marine fuel. Moreover, hydrogen production by electrolysis is an opportunity to store and transport surplus renewable energy, thus balancing the generation of energy from solar or wind power plants.

\subsection{Alternative energy storage technologies}

As technology advances, research works on new propulsion systems for ships. The most important of these technologies are fuel cells and battery systems.

Fuel cells are an efficient way of generating electricity with low carbon emission by hydrogen oxidation, which high electrochemical efficiency. During oxidation, hydrogen atoms react with oxygen atoms to form water and electrons flow in the form of an electric current through the external circuit. This direct conversion provides high electrical efficiency up to $60 \%$, depending on the type of fuel cell and fuel used and results in lower noise and vibration levels than conventional engines. The most promising for offshore use are solid oxide fuel cells (SOFC), proton exchange membrane fuel cells (PEMFC) and high temperature proton exchange membrane fuel cells (HT-PEMFC). The Viking Lady is the first ship equipped with fuel cells powering the main propulsion system in combination with a LNG-powered diesel engine in a hybrid ship model. This system has reduced emissions of SOx by $100 \%$, NOx by $85 \%$ and $\mathrm{CO}_{2}$ by $20-30 \%$. Fuel cells were widely used in spacecraft and submarines and its applicability to ships have promising future-oriented features in terms of alternative propulsion systems.

Battery equipped systems are more manageable and easily optimized in terms of performance, safety and fuel efficiency. The coverage of basic energy requirements of ancillary equipment with battery systems can reduce overall energy consumption, especially under dynamic loads (crane, deck equipment, etc.). The lithium nickel manganese cobalt 
oxide $(\mathrm{LiNiMnCoO})$ batteries are the preferred solutions in the marine industry due to its long service life and its sufficient specific energy. Fully electric ships are in perspective an important solution, but battery systems are still currently usable in limited applications, such as ferries and short sea travel.

\subsection{Treatment of exhaust gases technologies}

To control emissions of NOx and SOx and particulate, selective catalytic reduction (SCR) systems and exhaust gas recirculation (EGR) systems and exhaust gas cleaning systems (EGCS), are today available.

Installing a SCR system (Fig. 1) is an abatement technique to meet International Maritime Organization (IMO) Tier III NOx emission limits. It reduces the level of NOx in the exhaust gas using urea as the reducing agent and the vanadium pentoxide $\mathrm{V}_{2} \mathrm{O}_{5}$ supported on titanium dioxide $\left(\mathrm{TiO}_{2}\right)$ as dominant component of the catalysts [8]. The reduction reaction, taking place on the catalyst, can proceed at a speed depending on the ratio of NOx. The reaction finally produces ammonia $\left(\mathrm{NH}_{3}\right)$ and carbon dioxide $\left(\mathrm{CO}_{2}\right)$. The nitrogen oxide (NOx) emissions from the exhaust gas then react with ammonia $\left(\mathrm{NH}_{3}\right)$ on the catalyst surface and converts itself into nitrogen $\left(\mathrm{N}_{2}\right)$ and water $\left(\mathrm{H}_{2} \mathrm{O}\right)$. The catalytic elements are into the metal structure of the exhaust pipe. The efficiency of the catalytic reduction depends on a number of factors, including the dose of the reducing agent, the volume of catalytic elements and the temperature of the exhaust gases. Typically, NOx emissions can decrease by $90 \%$.

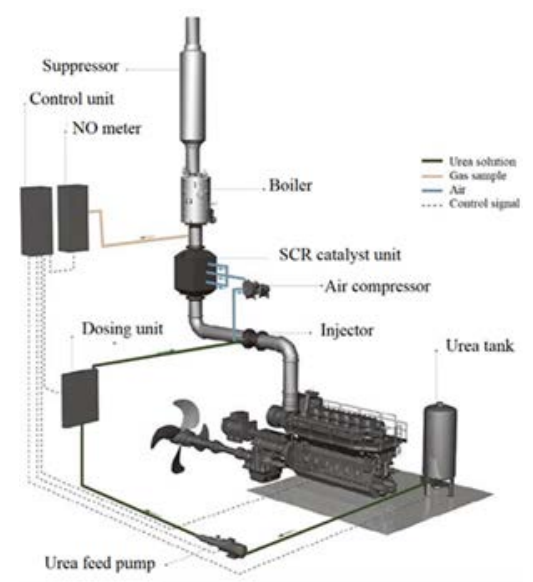

Figure 1: Components of a selective catalytic reduction (SCR) system. (Source: MAN.)

In the EGR systems, after cooling and cleaning the exhaust gases in the recirculation system, some of them direct back to the combustion area. Thus, part of the oxygen $\left(\mathrm{O}_{2}\right)$ in the combustion area is replaced by carbon dioxide $\left(\mathrm{CO}_{2}\right)$ generated during combustion. Since carbon dioxide $\left(\mathrm{CO}_{2}\right)$ has a higher heat capacity than oxygen $\left(\mathrm{O}_{2}\right)$, this reduces the maximum cylinder temperature during combustion. The burning rate decreases with the temperature. Since the nitrogen oxide formation rates depend on the combustion temperatures in the cylinders of the diesel engines, it affects the formation of $\mathrm{NO}_{\mathrm{x}}$ with the decreasing combustion rate to meet the requirements of IMO Level III. An example of EGR system application for a two-stroke diesel engine in Fig. 2. 


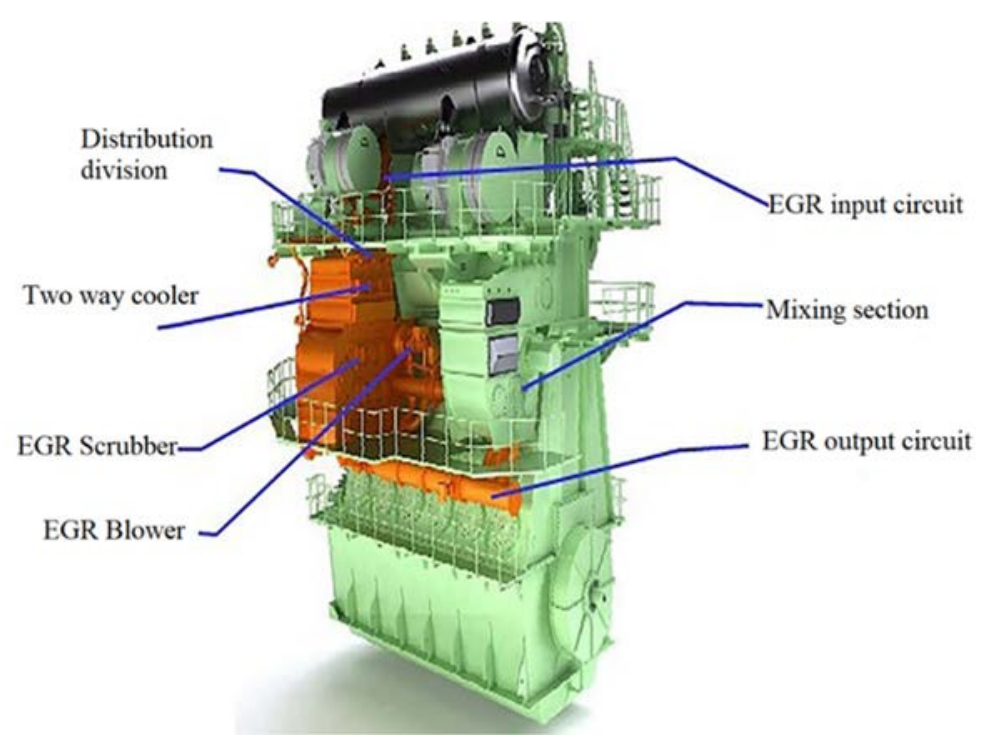

Figure 2: Application of the exhaust gases recirculation (EGR) system for a two-stroke diesel engine. (Source: MAN.)

Finally, exhaust gas cleaning systems (EGCS) or Scrubber systems, installed in the exhaust system after the engine or boiler, are able to reduce the level of particulate matter and sulphur oxides. After the washing process, sulphur oxide and exhaust gases with reduced level of particulate matter release to the atmosphere. Scrubber technologies used in ships are of three different typologies as below.

Open loop systems use seawater, preferred for the cleaning of exhaust gases thanks to its chemical composition; therefore, the expected operational area of the ship is relevant for the design and the selection of the system. For not alkaline waters, the scrubber system do not meet the required performances and it will need low sulphur fuel to comply with current SOx emission regulations. Used seawater goes back to the sea. Washing water flow rate in open loop systems is approximately $45 \mathrm{~m}^{3} / \mathrm{MWh}$. The investment costs are normally variable between 2.0 (new ships) and 2.4 million Euro (converted ships). Meanwhile the variable costs are in the range between 40 (new ships) and 60 (converted ships) Euro/kW.

Closed loop systems use fresh water post-treated with sodium hydroxide $(\mathrm{NaOH})$ in order to return it to the cleaning system. Typically, the cycle rate in a closed system is around 20 $\mathrm{m}^{3} / \mathrm{MWh}$ [9]. They discharged small amounts of treated washing water (about $0.1 \mathrm{~m}^{3} / \mathrm{MWh}$ ) in order to prevent the deterioration of the quality of fresh water used in the cleaning process.

Hybrid systems is a combined form of open and closed loop systems using seawater in open loop mode, where the alkalinity is high enough to ensure an effective cleaning; differently they use fresh water with chemicals additives in closed loop mode. The investment costs of these systems are normally higher because they require the duplication of pumps, cooling units for washing water, sludge tanks and pipe sets. In this case the costs are variable between 2.6 (new ships) and 3.1 million Euro (converted ships). Meanwhile the variable costs are in the range between 50 (new ships) and 65 (converted ships) Euro/kW. In addition, the system must switch to closed loop mode wherever regulations against the discharge of washing water are in force. It is the case in Bahrain, Belgium, China (Beihai, Dandong, 
Dalian and Yantai), Germany (inland ports), Ireland (Dublin), Latvia, Lithuania, Malaysia, Pakistan (Karachi), Portugal, Singapore, UK (Gibraltar), United Arab Emirates (Abu Dhabi and Fujairah), USA (California, Connecticut and Hawaii), the Panama and the Suez Canals.

\subsection{Use of renewable energy sources}

Ship propulsion systems moved from the times when human power and wind energy were dominating, to propulsion systems using steam power obtained by burning solid fuels and to the days of when petroleum derivatives intensive use. Today the ships can operate with various sustainable sources (e.g. solar, wind and hydrogen), possibly in combination to provide uninterrupted energy supply by complementing each other sustainable sources. It allows important developments in reducing environmental pollution in coastal areas and ports. The Norwegian Parliament recently decided to stop emissions from cruise ships and ferries in the Norwegian World Heritage fjords to make the fjords the world's first zeroemission zone by 2026. Indeed, the use of technologies enabling ships to sail with low or zero emission has become a necessity in sensible areas, paving the way for innovative approaches in the use of energy systems at sea and operational models based on various alternatives are using hybrid power systems by innovative approaches. In this context, shipbuilders and ship-owners sought solutions based on environmentally friendly alternative propulsion systems.

Solar cells, whose origins dated back to the 1800 s, represent an environmentally clean energy source in terms of their economic maintenance and sustainability within the framework of the technological advances made after the 1970s, when the efforts to utilize solar energy gained momentum. They became usable in the maritime sector because of the reduction of installation costs.

Moreover, developments in the use of renewable energy resources increased the interest for alternative energy supply from landside, covering the electrical energy needs during the time spent in ports, where the connection to the land power network is realistic. The electricity supply from the coast (cold ironing) started in 1989 in Gothenburg (Sweden) and continued in various other countries [10], especially for cruise and passengers ships. Moreover, this technique is able to combine the control of air and noise pollution thanks to the switching-off of diesel generators.

\section{COSTS AND BENEFITS OF EMISSION ABATEMENT METHODS}

\subsection{Investment and operational costs}

When determining the preferred emission reduction method, factors such as the regions where the ship operates and the age of the play an important role. While choosing the preferred reduction methods, the specific fuel consumption of the machine can increase, except for the initial installation costs. Therefore, a key role for any decision is the price of fuels, which is typically fluctuating a lot because of socio-economic and political local and global contingencies, very difficult to predict (Fig. 3) and a correct fleet planning is fundamental to prevent financial difficulties of ship-owners.

The investment capital costs (CAPEX) for the Scrubber systems include the equipment itself, design, installation (crew's expenses and income earned during the process, 2-4 weeks long) and the documentation (fees and expenses in connection with drafting and negotiation). Meanwhile, the operational costs (OPEX) consist of maintenance, chemicals to be used for closed loop and hybrid systems), water cleaning, additional energy need and losses [11]. 


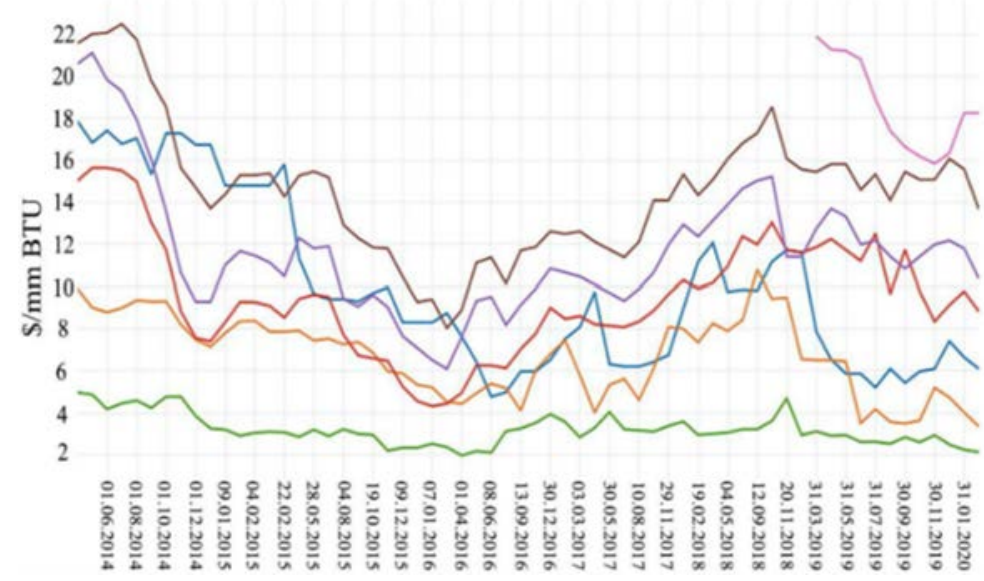

Figure 3: Fluctuation of fuel prices in the period 2014-2020: Japan gas (blue), Henry Hub (green), Europe gas (yellow), IFO 380 (red), crude-Brent (purple), $0.10 \mathrm{~m} / \mathrm{m}$ MGO (brown), methanol (pink).

On a completely different field, the costs for two- and four-stroke LNG machines are high (800-900 Euro/kW for converted engines and 1600-1800 Euro/kW for new engines) mainly due the spread of LNG transfer stations and the scarcity of trained personnel. Moreover, the scarcity of LNG refuelling points introduces constraints for ships' operators to correctly plan the navigation, which has an impact on fuel costs for dual-fuel engines. While the new generation dual fuel machines consume less compared to traditional two-stroke machines, they also enable the use of MGO when desired.

Nevertheless, in a preliminary cost/benefit analysis of commercial cases for standard LNG configurations conducted by the European Union in 2017, dual-fuel engines resulted to operate $95-99 \%$ in LNG mode and 1-5\% in diesel mode. Meanwhile the average LNG price in 2020 was around 170 Euro/t, though with relevant variability by bunker ports and other factors.

\subsection{Cost-benefit analysis approach}

The adaption of the classical cost-benefit approach to the specific application is in the following expression for the calculation of the Net Present Value (NPV) [12]:

$$
N P V=-C A P E X+\frac{1-(1+r)^{-t}}{r}(B-O P E X)
$$

where $B$ is the estimated emission reduction benefit, $r$ is the interest rate and $t$ the expected usage time of the implemented emission reduction method.

Since the lifetime of new and existing ships are different, their NPV are not directly comparable and the comparison is more effective by the Equivalent Annual Net Benefit (EANB):

$$
E A N B=\frac{N P V}{\left(\frac{1-(1+r)^{-t}}{r}\right)} .
$$


Moreover, since the fuels used in ships do not have a technical life and their use is practically endless, in the NPV calculation total benefits and costs should be referred both to the interest rate and a powerful indicator becomes the Pay-Back-Period for the investment, which indicated the duration of investment recovery.

$$
P B P=\frac{C A P E X+O P E X}{O P E X(F U E L)}
$$

where OPEX (FUEL) is the annual cost due to the fuel consumption of the ship.

Should the obtained value be longer than the ship expected operating life, the investment would be not recommendable.

The conversion factor between fuel consumption and $\mathrm{CO}_{2}$ emissions depends on a set of parameters, such as the fuel typology (liquid or gas), its density, lower calorific value, filling rate of the tank, total engine power (single or dual fuel). Moreover, in order to make maritime transport cleaner, the International Maritime Organisation adopted the Energy Efficiency Design Index (EEDI), as a global regulation of $\mathrm{CO}_{2}$ emissions across the industry. The lower the EEDI is, the more energy efficient the ship is.

\subsection{Analysis for a case study ship}

This section develops the annual emission estimation of a commercial bulk cargo ship and the calculation of its environmental cost by integrating the abatement methods and the corresponding environmental benefits. It will take into account the regions, where the ship operates, and the CAPEX and OPEX costs of the emission reduction options.

The main characteristic of the ship are as follows:

- Dimensions: $190 \times 32 \times 18 \mathrm{~m}$;

- DWT: 56,000;

- Host power: 9,500 kW;

- Auxiliary power: $1,650 \mathrm{~kW}$;

- Maximum speed: 14.5 knots;

- Specific fuel consumption: 170-195 g/kWh;

- Year of construction: 2005.

In 2018, the ship operated in non-ECA regions with the following distribution of operating periods in 2018: $51 \%$ cruising, $34 \%$ ports, $11 \%$ manoeuvring and $4 \%$ anchorage. In the same period, the main engine load was variable on monthly basis, as from Fig. 4.

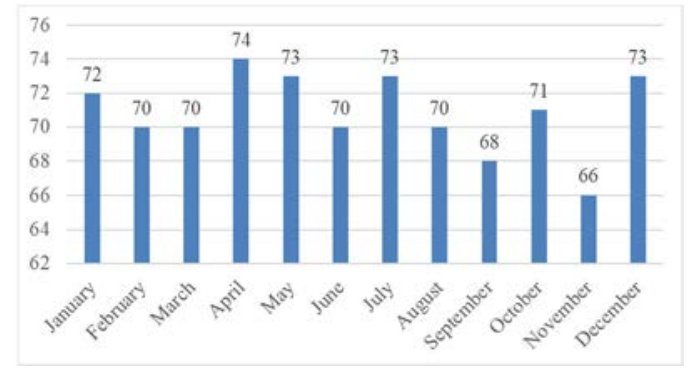

Figure 4: Monthly main engine average loads (tons $\left.\times 10^{3}\right)$. 
The first comparison is between the current situation, with combined use of HFO and MGO, and the implementation of dual fuel, with combined use of LNG and MGO for main engine and generators. The corresponding calculated consumption that will occur are as in Table 1.

Table 1: Annual average fuel consumption in current situation and with dual fuel engine implementation.

\begin{tabular}{|l|c|c|}
\hline Scenario & Fuel type & Consumption [t/year] \\
\hline \multirow{2}{*}{ Current } & HFO & 5,160 \\
\cline { 2 - 3 } & MGO & 153 \\
\hline \multirow{2}{*}{ Dual fuel } & LNG & 5,248 \\
\cline { 2 - 3 } & MGO & 112 \\
\hline
\end{tabular}

The application of appropriate conversion factors [13] allows at calculating the amount of emissions in all scenarios characterized by the implementation of various technological scenarios for the reduction of the emissions, as defined in Table 2.

Table 2: Annual amount of exhaust emissions calculated for all considered scenarios (t/year).

\begin{tabular}{|l|c|c|c|c|c|}
\hline Scenario & $\mathrm{CO}_{2}$ & $\mathrm{NO}_{x}$ & $\mathrm{SO}_{x}$ & $\mathrm{PM}_{10}$ & $P M_{2.5}$ \\
\hline Current & 16,561 & 460 & 106 & 45 & 40 \\
\hline MGO & 17,036 & 464 & 11 & 8 & 8 \\
\hline VLSFO & 16,941 & 460 & 32 & 16 & 14 \\
\hline Scrubber & 16,727 & 464 & 2 & 1 & 1 \\
\hline Scrubber + SCR & 16,727 & 46 & 2 & 1 & 1 \\
\hline Dual fuel & 14,790 & 51 & 2 & 1 & 1 \\
\hline
\end{tabular}

The following step is the calculation of the costs corresponding to damages caused by the exhaust emissions resulting from one-year fuel consumption of a ship. The cots factors are those resulting from [14] with reference to the EU countries and the results obtained are in Table 3.

Table 3: Annual environmental costs generated by exhaust emissions in various technological scenarios (kEuro/year).

\begin{tabular}{|l|c|c|c|c|c|c|}
\hline Scenario & $\mathrm{CO}_{2}$ & $\mathrm{NO}_{x}$ & $\mathrm{SO}_{x}$ & $P M_{10}$ & $P M_{2.5}$ & Total \\
\hline Current & 1,130 & 8,191 & 1,472 & 1,446 & 2,105 & 14,344 \\
\hline MGO & 1,162 & 8,191 & 147 & 273 & 372 & 10,145 \\
\hline VLSFO & 1,155 & 8,191 & 441 & 507 & 675 & 10,969 \\
\hline Scrubber & 1,141 & 8,273 & 36 & 30 & 38 & 9,518 \\
\hline Scrubber + SCR & 1,141 & 827 & 36 & 30 & 38 & 2,072 \\
\hline Dual fuel & 1,009 & 905 & 32 & 36 & 53 & 2,035 \\
\hline
\end{tabular}

The corresponding calculation of the Net Present Values (NPV) must take into account the different lifetime of the options, as well as the presence or absence of initial setup costs and operating costs. However, as anticipated in Section 3.2, in order to compare the systems 
in these conditions, equivalent annual net benefit (EANB) is the key indicator. For the scenarios including the implementation of new technologies, the investment and operational costs of different systems, calculated basing on the factor costs highlighted in Section 2.3, are as in Table 4.

Table 4: Investment and operational costs in various technological scenarios.

\begin{tabular}{|l|c|c|}
\hline Scenario & $\begin{array}{c}\text { Investment cost } \\
\text { (kEuro) }\end{array}$ & $\begin{array}{c}\text { Operational cost } \\
\text { (kEuro/year) }\end{array}$ \\
\hline SCR & 730 & 203 \\
\hline Open Loop Scrubber & 3,103 & 33 \\
\hline Hybrid Scrubber & 3,685 & 38 \\
\hline Open Loop Scrubber + SCR & 3,833 & 235 \\
\hline Hybrid Scrubber + SCR & 4,414 & 242 \\
\hline Dual fuel & 17,094 & 914 \\
\hline
\end{tabular}

According to the annual fuel consumption of the ship (Table 1) and the price of the various concerned typologies of fuel [15], the calculated annual fuel costs are in Table 5.

Table 5: Annual costs for various fuels combinations (kEuro/year).

\begin{tabular}{|l|c|}
\hline Fuels & Annual cost (kEuro) \\
\hline MGO & 2,744 \\
\hline MGO + VLSFO & 1,922 \\
\hline MGO + HFO & 1,413 \\
\hline MGO + LNG & 914 \\
\hline
\end{tabular}

The technical life of the systems is the same as the remaining operating life of the ship (15-year) considering an average technical life of 30 years for the ship built in 2005. The interest rate was $5 \%$ as stated in [11]. Basing on these parameters, in Table 6 , the calculated NPV and EANB values.

Table 6: Net present value (NPV) and equivalent annual net benefit (EANB) in various technological scenarios (kEuro).

\begin{tabular}{|l|c|c|}
\hline Scenario & NPV & EANB \\
\hline MGO & 29,105 & - \\
\hline MGO + VLSFO & 29,049 & - \\
\hline Open Loop Scrubber & 46,721 & 4,501 \\
\hline Hybrid Scrubber & 46,077 & 4,440 \\
\hline Open Loop Scrubber + SCR & 121,164 & 11,673 \\
\hline Hybrid Scrubber + SCR & 120,519 & 11,612 \\
\hline Dual fuel & 101,190 & 949 \\
\hline
\end{tabular}

Finally, in terms of pay-back period (PBP), the various technological scenarios are resulting as in Table 7. 
Table 7: Pay-back period (PBP) in various technological scenarios (years).

\begin{tabular}{|l|c|}
\hline Scenario & $P B P$ \\
\hline Open Loop Scrubber & 2.2 \\
\hline Hybrid Scrubber & 2.6 \\
\hline Open Loop Scrubber + SCR & 2.9 \\
\hline Hybrid Scrubber + SCR & 3.3 \\
\hline Dual fuel & 12.7 \\
\hline
\end{tabular}

\section{CONCLUSIONS}

The study presented a methodology for the systematic estimation of the exhaust emissions of commercial ships and its environmental costs, in addition to a comparative analysis of emissions abatement methods. The test of the methodology was on a bulk carrier ship with reference to a one-year operation. By a cost-benefit analysis of alternative emission reduction scenarios.

In order to reduce ship-related emissions, it is necessary to integrate new systems in line with technological developments. However, as mentioned before, the use of selected additional systems or changes in the fuel type cause reductions in certain emission types, while the implementation of additional systems will cause a slight increase in fuel consumption and corresponding increases in $\mathrm{CO}_{2}$ emission.

In the installation of scrubber systems, the preference is for open loop systems, which are anyway disputable because many countries prohibit the use of these systems due to the washing water going back to the sea. Meanwhile the hybrid scrubber systems are effective but expensive solutions. Moreover, an additional handicap of the scrubber systems is the inadequate knowledge and experience of the personnel in the operation of the systems.

The use of VLSFO, considering the change in global fuel prices, stands out as a significant disadvantage for ship-owners due to its high prices. In the process of compliance with IMO 2020 Sulphur regulations, they normally prefer the use of MGO due to its more reasonable price.

LNG is a concrete alternative to comply with emission restrictions both for existing and new ships. The most important benefits are the almost zero SOx and PM emissions that can make ships compliant with IMO Tier III limits in terms of NOx emissions, without the need for an exhaust gas cleaning system. The disadvantages are here in terms of expensive dual fuel engines and inhomogeneous refuelling ports distribution.

From a purely cost viewpoint, the most appropriate option among emission reduction methods is to use MGO, which does not require installation costs and provides an additional advantage for the ships that work in ECA, meanwhile VLSFO results the best option for ship operating outside the ECA.

From a global viewpoint, the PBP of the investments show that the recovery is possible by $2-3$ years, except for the switch to dual fuel engines, whose PBP is about 13 years, not reasonable for ships in operation since long times.

The further developments of the research should start from focusing on the extension of the test to a large set of ships by variating typologies, dimensions, operating range and age. Moreover, it is necessary to tackle the reliable calculations of the Energy Efficiency Design Index (EEDI), which could bring additional advantages to the use of LNG and could qualify the value of the ships in case of sale in a second hand market, by reclaiming profit margins, especially in case of low freight rates and volatile fuel prices. Moreover, customers, shipowners and charters are increasingly aware of the negative environmental impact of transport 
and the hidden potential that a more sustainable shipping could bring in increasing demand of environmentally conscious customers.

\section{REFERENCES}

[1] Rotoli, F., Calcagno, G., Alda, S., Garcia Horrillo, M., Ricci, S. \& Rizzetto, L., Preliminary cost-effectiveness analysis of the measures put in place by EU Member States to implement the directive on reduction of sulphur content in fuels used by ships. WIT Transactions on the Built Environment, vol. 187, WIT Press: Southampton and Boston, 2019.

[2] Wang, C., Corbett, J.J. \& Firestone, J., Modelling energy use and emissions from North American shipping: Application of the ship traffic, energy, and environment model. Environmental Science and Technology, 41(9), pp. 3226-3232, 2007.

[3] Jafarzadeh, S., Paltrinieri, N., Utne, I.B. \& Ellingsen, H., LNG-fuelled fishing vessels: A systems engineering approach. Transportation Research Part D: Transport and Environment, 50, pp. 202-222, 2017.

[4] DNV GL. Assessment of selected alternative fuels and technologies. IMO, 391(June), pp. 1-48, 2018.

[5] Balcombe, P., Brierley, J., Lewis, C., Skatvedt, L., Speirs, J., Hawkes, A. \& Staffell, I., How to decarbonise international shipping: Options for fuels, technologies and policies. Energy Conversion and Management, 182, pp. 72-88, 2019.

[6] Ammar, N.R., An environmental and economic analysis of methanol fuel for a cellular container ship. Transportation Research Part D: Transport and Environment, 69, pp. 66-76, 2019.

[7] Mohd Noor, C.W., Noor, M.M. \& Mamat, R., Biodiesel as alternative fuel for marine diesel engine applications: A review. Renewable and Sustainable Energy Reviews, 94, pp. 127-142, 2018.

[8] Magnusson, M., Fridell, E. \& Ingelsten, H.H., The influence of sulphur dioxide and water on the performance of a marine SCR catalyst. Applied Catalysis B: Environmental, pp. 111-112, 2012.

[9] Exhaust Gas Cleaning Systems Association, A practical guide to exhaust gas-cleaning systems for the maritime industry. EGCSA Handbook, London, 2012.

[10] Marinacci, C., Masala, R., Ricci, S. \& Tieri, A., Technical-economical and financial analysis of cold-ironing: Case study of cruise terminal of port of Venice. 5th International Conference on Computational Methods in Marine Engineering MARINE 2013, pp. 564-570.

[11] Panasiuk, I. \& Turkina, L., The evaluation of investments efficiency of SOx scrubber installation. Transportation Research Part D: Transport and Environment, 40(2015), pp. 87-96, 2015.

[12] Jiang, L., Kronbak, J., Christensen, L.P., The costs and benefits of sulphur reduction measures: Sulphur scrubbers versus marine gas oil. Transportation Research Part D: Transport and Environment, 28, pp. 19-27, 2014.

[13] European Environment Agency, EMEP/EEA air pollutant emission inventory guidebook 2019. Technical guidance to prepare national emission inventories - EEA Report n. 13/2019, Copenhagen.

[14] De Bruyn, S., Bijleveld, M., Schroten, A., Vergeer, R. \& Ahdour, S., Environmental Prices Handbook. EU28 Version. CE Delft, p. 175, 2018.

[15] DNV GL, Current price development oil and gas, 2020. https://www.dnv.com/ maritime/insights/topics/lng-as-marine-fuel/current-price-development-oil-andgas.html. 